\title{
RESPON BEBERAPA VARIETAS TANAMAN JAGUNG (Zea mays L) PADA BERBAGAI SISTEM TANAM
}

\section{(Response of Some Varieties of Maize Crops (Zea mays L) at Different Planting System)}

\author{
Ahmad Haris Haruna ${ }^{1)}$, St. Subaedah ${ }^{2)}$, St. Sabahannur ${ }^{2)}$ \\ ${ }^{1)}$ Balai Penelitian Tanaman Serealia, Maros \\ ${ }^{2)}$ Fakultas Pertanian, Universitas Muslim Indonesia Makassar
}

\begin{abstract}
This study was conducted with the aim of analyzing the growth and yield of Nasa 29, Bisi 2, and Bima19 URI corn varieties on various planting systems. This research was carried out in the BALITSEREAL Bajeng Experiment Garden, Gowa, South Sulawesi which took place from May to September 2017. The experiments were arranged in the form of Split Plot Design. As the main plot is corn varieties consisting of 3 varieties: NASA 29, Bisi 2, and Bima 19 URI, while the plot is a planting system consisting of two planting systems namely Legowo row planting system and conventional planting system.The results of this study indicate that: Bisi 2 varieties of corn have good growth, which is shown by the highest plant height and has the longest leaves. Nasa 29 varieties produce the longest cob length compared to other varieties. The conventional planting system obtained a larger cob diameter of $46.51 \mathrm{~mm}$ compared to the legowo 2:1 cropping system with an average ear diameter of $44.97 \mathrm{~mm}$. The interaction between the Bisi 2 variety and the conventional planting system obtained a cob with the largest cob diameter.
\end{abstract}

Keywords : Corn, varieties, cropping systems, Jajar Legowo

\section{PENDAHULUAN}

Beberapa tahun terakhir proporsi penggunaan jagung oleh industri pakan telah mencapai 50\% dari total keseluruhan kebutuhan nasional. Dalam 20 tahun kedepan, penggunaan jagung untuk pakan diperkirakan terus meningkat bahkan setelah tahun 2020 penggunaan jagung untuk kebutuhan pakan diperkirakan lebih dari $60 \%$ dari total kebutuhan nasional. Dengan meningkatnya kebutuhan jagung setiap tahunnya, maka budidaya tanaman jagung sangat menguntungkan dan mempunyai prospek cukup baik bagi yang mengusahakannya (Suryana, 2005 dalam Kaswan dan Amzeri, 2011)

Produksi jagung di Sulawesi Selatan pada tahun 2014 sebanyak 1,49 juta ton pipilan kering yang diperoleh dari luas panen 289,74 ribu hektar dan tingkat produktifitas 51,46 kuintal per hektar dan pada tahun 2015 produksi jagung sebanyak 1,53 juta ton pipilan kering, mengalami kenaikan sebanyak 37,42 ribu ton $(2,51 \%)$ dibandingkan tahun 2014. Kenaikan produksi terjadi karena kenaikan luas panen seluas 5,38 ribu hektar $(1,86 \%)$ dan produktifitas sebesar 
0,33 kuintal per hektar $(0,64 \%)$ (BPS, Dengan demikian diperlukan usaha 2016). diseminasi melalui display VUB dan gelar

Rendahnya produksi jagung di Indonesia dipengaruhi oleh beberapa faktor penyebab antara lain, tingginya harga benih varietas unggul, petani belum memahami penggunaan pupuk secara tepat dan benar, minimnya permodalan serta penggunaan pestisida yang berlebihan pada areal pertanaman oleh pelaku usaha tani dapat mengakibatkan terjadinya resistensi hama terhadap pestisida, dan pada waktu yang sama keberadaan musuh alami hama di areal lahan pertanian terancam punah yang membawa dampak negatif yaitu terjadinya ledakan serangan hama, akibatnya dapat menurunkan hasil produksi pertanian (Suprapato dan Nyoman, 2000).

Badan Penelitian dan Pengembangan Pertanian melalui Balai Penelitian Tanaman Serealia (Balitsereal) Maros telah menghasilkan varietas baru jagung komposit maupun hibrida dan sudah melepas lebih dari 20 varietas yang telah disebarkan 16 ton benih selama 2005-2010 (Yasin 2010). Varietas jagung hibrida dari Bima 1 sampai Bima 15 hasil Badan Litbang Pertanian, masih belum banyak dikenal di masyarakat petani. teknologi VUB jagung sehingga dapat dikenal dan berkembang di masyarakat.

Selain itu berbagai pola pengaturan jarak tanam telah dilakukan guna mendapatkan produksi yang optimal. Penggunaan jarak tanam pada tanaman jagung dipandang perlu, karena untuk mendapatkan pertumbuhan tanaman yang seragam, distribusi unsur hara yang merata, efektivitas penggunaan lahan, memudahkan pemeliharaan, menekan pada perkembangan hama dan penyakit juga untuk mengetahui berapa banyak benih yang diperlukan pada saat penanaman.

Tujuan penelitian adalah untuk mengkaji (1) pertumbuhan dan produksi tanaman jagung varietas Nasa 29, Bisi 2, Bima 19 URI (2) pertumbuhan dan produksi tanaman jagung dari dua sistem tanam dan (3) interaksi antara varietas dengan sistem tanam terhadap pertumbuhan dan produksi tanaman jagung.

\section{METODE PENELITIAN}

Penelitian ini dilaksanakan di Kebun Percobaan BALITSEREAL Bajeng, Kab. Gowa Sulawesi Selatan. Penelitian 
dilaksanakan pada bulan Mei sampai hari setelah tanam (hst) dengan pemberian September 2017. Penelitian ini pupuk Urea dengan dosis 2,25 menggunakan rancangan Split Plot Design gram/tanaman, NPK Phonska 15:15:15 terdiri dari petak utama dan anak petak. dengan dosis 3,4 gram/tanaman. Sebagai petak utama adalah varietas Pemupukan kedua dilakukan pada umur tanaman jagung yang terdiri dari 321 hari setelah tanam (hst) yaitu varietas yaitu V1: Varietas Nasa 29, V2: pemberian Urea dengan dosis 2,25 Varietas Bisi 2, V3: Varietas Bima19 gram/tanaman. Cara pemberian pupuk URI. Sebagai anak petak adalah sistem dilakukan dengan cara ditugal yang dibuat tanam yang terdiri dari 2 sistem tanam dengan jarak $7-8 \mathrm{~cm}$ dari lajur lubang yaitu: L: Sistem tanam Legowo dan K : tanam jagung dengan kedalaman 8- 10 Sistem tanam Konvensional. Pengolahan $\mathrm{cm}$. Tinggi tanaman diukur pada umur 60 tanah dilakukan dengan cara membajak hari setelah tanam dari dasar tanaman di tanah dua kali kemudian dilakukan permukaan tanah sampai pangkal terakhir penggaruan untuk menghancurkan bunga jantan. Jumlah sampel sebanyak 6 bongkahan tanah dan dilakukan perataan serta rotsrin untuk lebih memperhalus tekstur tanah. Benih yang digunakan adalah benih jagung varietas Nasa 29, Bisi 2, dan Bima 19 URI. Jarak tanam (100 x 50) $\mathrm{cm} \times 20 \mathrm{~cm}$ dan $75 \mathrm{~cm} \times 20 \mathrm{~cm}$. tanaman dipilih secara acak disetiap kombinasi perlakuan. Diameter batang tanaman diukur sejak umur tanaman 4 MST. Pengukuran diameter batang dilakukan dengan menggunakan jangka sorong pada pangkal batang. Panjang daun Penanaman dilakukan dengan membuat lubang tanam sedalam $3-4 \mathrm{~cm}$, tiap lubang tanam ditanami 3 benih jagung dengan jarak tanam yang disesuaikan diukur dari pangkal daun sampai ujung daun dengan menggunakan meteran. Daun yang diukur adalah daun yang terpanjang. Pengukuran ini dilakukan pada minggu ke dengan ketentuan perlakuan. Pemupukan 2 setelah tanam. Panjang daun diamati dilakukan dengan menggunakan pupuk pada umur 6 minggu setelah tanam (mst) Urea dan NPK Phonska dengan dosis sebanyak 6 sampel tanaman dipilih secara yang berbeda. Pemupukan pertama acak. Lebar daun diukur pada umur 6 dilakukan pada saat tanaman berumur 10 minggu setelah tanam bersamaan pada 
saat pengamatan panjang daun. Pengolahan data pertumbuhan Pengambilan sampel sebanyak 6 tanaman vegetatif, generatif dan komponen hasil dengan menggunakan meteran. dianalisis menggunakan uji $F$ dengan Komponen hasil diambil dari sejumlah selang kepercayaan 95\%. Jika terdapat tongkol sampel yang telah dikeringkan. pengaruh nyata maka dilakukan uji lanjut Beberapa parameter yang diambil adalah; Beda Nyata Terkecil (BNT) pada taraf $\alpha$ panjang tongkol, diameter tongkol, bobot $5 \%$ tongkol, jumlah baris per tongkol, jumlah

\section{HASIL DAN PEMBAHASAN}

biji per baris, dan bobot 100 biji. Konversi

Hasil per petak ke t/ha pada K.A. $15 \%$, dihitung menggunakan rumus sebagai berikut :

$$
\text { Hasil }(\mathrm{kg} / \mathrm{ha})=\frac{10000}{L P} \times \frac{100-K A}{100-15} \times B \times R
$$

Keterangan :

$$
\begin{aligned}
& \text { K.A = Kadar Air Biji Panen. } \\
& \text { L.P = Luas Petakan Panen }(\mathrm{m} 2) . \\
& \text { B = Berat Tongkol Kupasan Basah }(\mathrm{kg}) \\
& \text { R= Rendemen biji dari tongkol }
\end{aligned}
$$

\section{a. Hasil}

\section{Tinggi Tanaman}

Berdasarkan hasil sidik ragam parameter tinggi tanaman jagung menunjukkan bahwa varietas berpengaruh nyata dan interaksi antara varietas dan sistem tanam berpengaruh sangat nyata sedangkan sistem tanam tidak

\begin{tabular}{|c|c|c|c|}
\hline \multirow{2}{*}{ Varietas } & \multicolumn{2}{|c|}{ Sistem Tanam } & \multirow{2}{*}{ BNT $5 \%$} \\
\hline & Legowo & Konvensional & \\
\hline Bima 19 URI & $213.78 \quad \mathrm{a}$ & 198.22 & \\
\hline Bisi 2 & $238.94 \quad \mathrm{a}$ & 240.72 & 6.719 \\
\hline Nasa 29 & $207.94 \quad b$ & $216.72 \quad \mathrm{a}$ & \\
\hline
\end{tabular}
berpengaruh nyata terhadap tinggi tanaman

Tabel 1. Rata-rata tinggi tanaman $(\mathrm{cm})$ beberapa varietas jagung yang ditanam pada sistem tanam yang berbeda

Hasil uji BNT 5\% pada Tabel 1 dan tidak berbeda nyata dengan Bisi 2 menunjukkan rata-rata tinggi tanaman yang ditanam secara legowo, sedangkan varietas Bisi 2 pada sistem tanam rata-rata tinggi tanaman terendah yaitu konvensional tertinggi yaitu 240,722 cm varietas Bima 19 URI pada sistem tanam 
konvensional dengan rata-rata tinggi menunjukkan varietas, sistem tanam, dan tanaman 198,222 cm. interaksi antara keduanya tidak

\section{Diameter Batang} berpengaruh nyata

Berdasarkan hasil sidik ragam terhadap parameter diameter batang

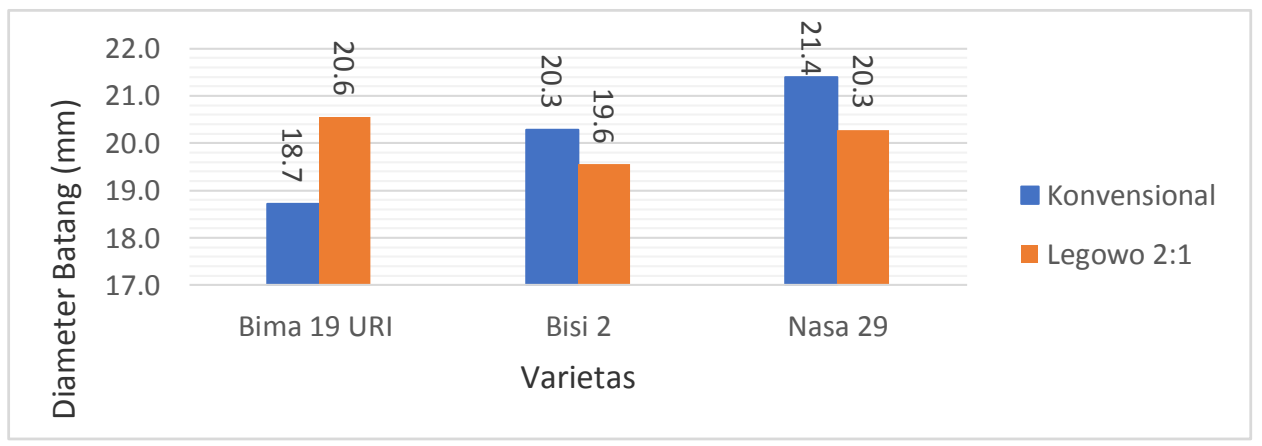

Gambar 1. Rata-rata diameter batang $(\mathrm{mm})$ beberapa varietas jagung yang ditanam pada sistem tanam yang berbeda

Gambar 1 menunjukkan bahwa rataTabel 2, hasil uji BNT 5\% rata-rata rata diameter batang beberapa varietas panjang daun beberapa varietas jagung, jagung pada sistem tanam yang berbeda, menunjukkan daun yang terpanjang menunjukkan rata-rata diameter batang adalah varietas Bisi 2 dengan rata-rata terbesar adalah varietas Nasa $29 \mathrm{~mm}$ panjang daun $100,047 \mathrm{~cm}$ sedangkan dengan rata-rata diameter batang $21,4 \mathrm{~mm}$ panjang daun terpendek adalah varietas sedangkan rata-rata diameter batang Bima 19 URI dengan rata-rata panjang terkecil adalah varietas Bima 19 URI daun 90,986 cm denga rata-rata diameter batang $18,7 \mathrm{~mm}$.

\section{Lebar Daun}

\section{Panjang Daun}

Hasil sidik ragam terhadap panjang

Berdasarkan hasil sidik ragam daun beberapa varietas jagung jagung menunjukkan varietas berpengaruh menunjukkan varietas berpengaruh sangat sangat nyata sedangkan sistem tanam dan nyata, sedangkan sistem tanam dan interaksi antara varietas dan sistem tanam interaksi antara varietas dan sistem tanam tidak berpengaruh nyata. tidak berpengaruh nyata. 
Ahmad Haris Haruna : Respon beberapa Varietas Tanaman Jagung (Zea mays L.) pada berbagai sistem Tanam

Tabel 2. Rata-rata panjang daun $(\mathrm{cm})$ beberapa varietas jagung yang ditanam pada sistem tanam yang berbeda

\begin{tabular}{|c|c|c|}
\hline Vatietas & Rata-rata & BNT 5\% \\
\hline Bima 19 URI & $90.986 \quad b$ & \\
\hline Bisi 2 & $100.047 \quad \mathrm{a}$ & 3.360 \\
\hline Nasa 29 & $98.083 \quad \mathrm{a}$ & \\
\hline
\end{tabular}

Tabel 3 menunjukkan bahwa ratarata lebar daun beberapa varitas jagung, menunjukkan daun yang terlebar adalah varietas Nasa 29 dengan rata-rata lebar daun 10,792 $\mathrm{cm}$ sedangkan daun yang terkecil adalah varietas Bisi 2 dengan ratarata lebar daun $9,386 \mathrm{~cm}$.

\section{Panjang Tongkol}

Pada hasil sidik ragam terhadap panjang tongkol beberapa varietas jagung, menunjukkan varietas berpengaruh sangat nyata, sedangkan sistem tanam dan interaksi antara varietas dan sistem tanam tidak berpengaruh nyata terhadap panjang tongkol.

Tabel 3. Rata-rata lebar daun $(\mathrm{cm})$ beberapa verietas jagung yang ditanam pada sistem tanam yang berbeda

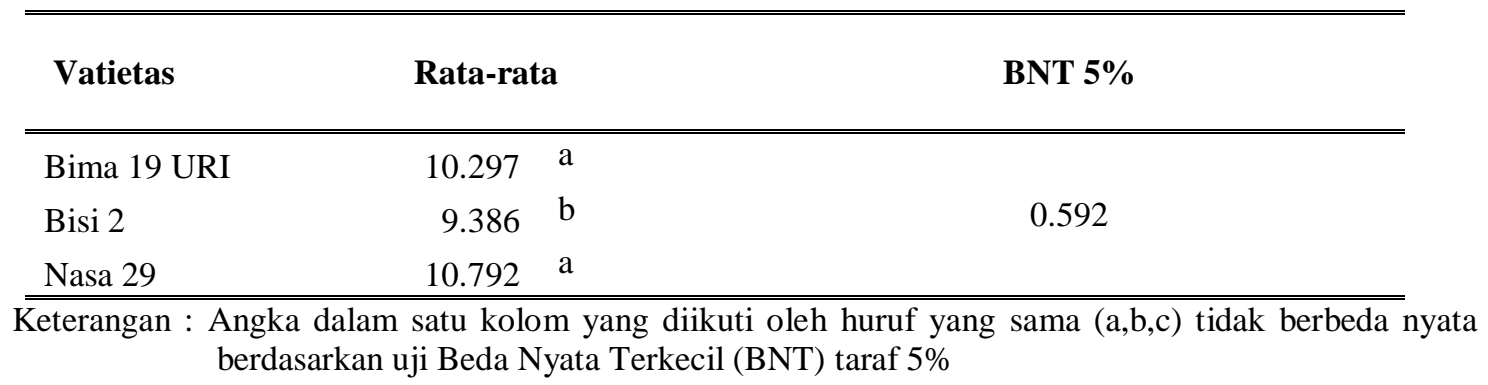

Tabel 4 menunjukkan bahwa ratarata panjang tongkol beberapa varietas jagung, menunjukkan tongkol yang terpanjang adalah varietas Nasa 29 dengan rata-rata panjang tongkol $18,6 \mathrm{~cm}$ dan berbeda nyata dengan varietas Bima 19
URI dan Bisi 2, sedangkan tongkol yang terpendek adalah varietas Bima 19 URI dengan rata-rata panjang tongkol 16,6 cm. 
Diameter Tongkol

Berdasarkan hasil sidik ragam terhadap diameter tongkol beberapa varietas jagung, menunjukkan verietas dan sistem tanam berpengaruh nyata, sedangkan interaksi antara varietas dan sistem tanam berpengaruh sangat nyata terhadap diamet tongkol.

Tabel 4. Rata-rata panjang tongkol $(\mathrm{cm})$ beberapa varietas jagung yang ditanam pada sistem tanam yang berbeda

\begin{tabular}{|c|c|c|}
\hline Vatietas & Rata-rata & BNT 5\% \\
\hline Bima 19 URI & $16.6 \mathrm{~b}$ & \\
\hline Bisi 2 & $17.4 \quad \mathrm{~b}$ & 0.862 \\
\hline Nasa 29 & $18.6 \mathrm{a}$ & \\
\hline
\end{tabular}

Keterangan : Angka yang diikuti oleh huruf yang sama tidak berbeda nyata berdasarkan uji Beda Nyata Terkecil (BNT) taraf 5\%

Tabel 5, hasil uji BNT 5\% rata-rata diameter tongkol beberapa varietas jagung, menunjukkan tongkol yang terbesar adalah varietas Bima 19 URI pada sistem tanam legowo dengan ratarata diameter tongkol $48,728 \mathrm{~mm}$ dan tidak berbeda nyata dengan varietas Bima 19 URI pada sistem tanam konvensional sedangkan tongkol yang terkecil adalah varietas Bisi 2 pada sistem tanam jajar legowo dengan rata-rata diameter tongkol $42,611 \mathrm{~mm}$.

Tabel 5. Rata-rata diameter tongkol ( $\mathrm{mm})$ beberapa varietas jagung yang ditanam pada sistem tanam yang berbeda

\begin{tabular}{|c|c|c|c|}
\hline \multirow{2}{*}{ Vatietas } & \multicolumn{2}{|c|}{ Sistem Tanam } & \multirow{2}{*}{ BNT 5\% } \\
\hline & Legowo & Konvensional & \\
\hline Bima 19 URI & $48.728 \quad \mathrm{a}$ & 48.551 & \\
\hline Bisi 2 & $42.611 \quad b$ & $42.758 \quad b$ & 1.900 \\
\hline Nasa 29 & $43.583 \mathrm{~b}$ & $48.249 \quad \mathrm{a}$ & \\
\hline
\end{tabular}

Keterangan : Angka dalam satu kolom yang diikuti oleh huruf yang sama tidak berbeda nyata berdasarkan uji Beda Nyata Terkecil (BNT) taraf 5\%

\section{Bobot Tongkol}

Berdasarkan hasil sidik ragam terhadap parameter bobot tongkol menunjukkan varietas, sistem tanam, dan interaksi antara keduanya tidak berpengaruh nyata. 
Berdasarkan Gambar 2. Rata-rata tongkol seluruhnya adalah $6,23 \mathrm{~kg}$ bobot tongkol beberapa Varietas jagung sedangkan bobot tongkol seluruhnya pada sistem tanam yang berbeda, yang teringan dalah varietas bima 19 menunjukkan rata-rata bobot tongkol URI dengan sistem tanam jajar legowo seluruhnya yang terberat adalah varietas dimana rata-rata bobot tongkol Bisi 2 dengan sistem tanam seluruhnya adalah $5,41 \mathrm{~kg}$. konvensional dimana rata-rata bobot

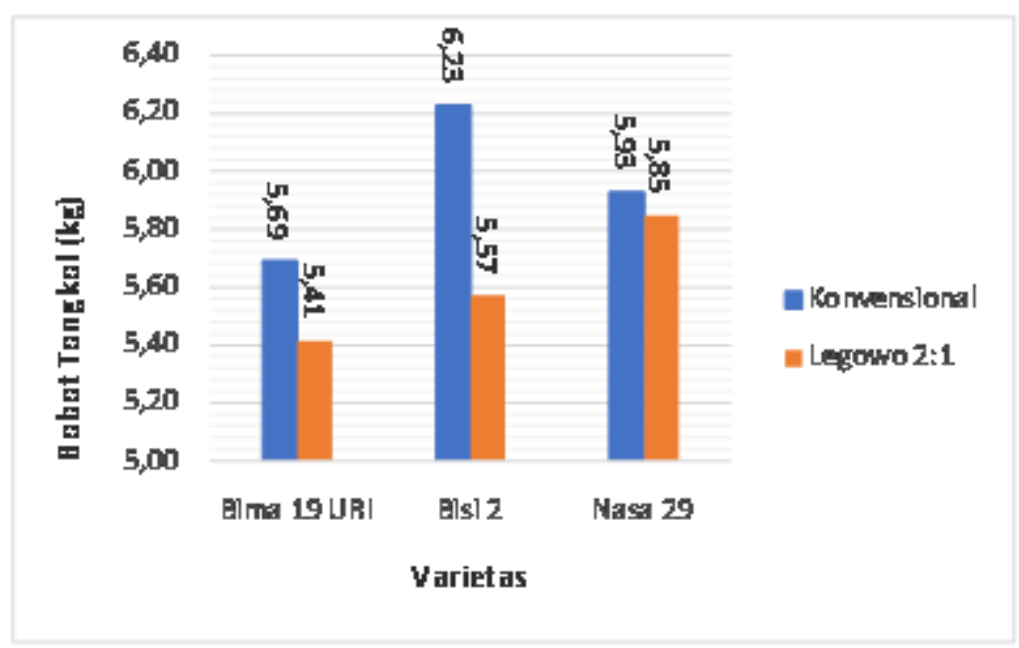

Gambar 2. Rata-rata bobot tongkol $(\mathrm{kg})$ beberapa Varietas jagung yang ditanam pada sistem tanam yang berbeda

\section{Hasil per Hektar}

Berdasarkan hasil sidik ragam terhadap parameter hasil per hektar menunjukkan varietas, sistem tanam, dan interaksi antara keduanya tidak berpengaruh nyata.

Berdasarkan Gambar 3. Rata-rata hasil beberapa Varietas jagung pada sistem tanam yang berbeda, menunjukkan rata-rata hasil yang terbanyak adalah varietas Nasa 29 dengan sistem tanam jajar legowo dimana hasilnya sebesar 10,5 ton/ha, sedangkan rata-rata hasil yang terendah adalah varietas Bima 19 URI dengan sistem tanam jajar legowo dimana hasilnya 9,0 ton/ha. 


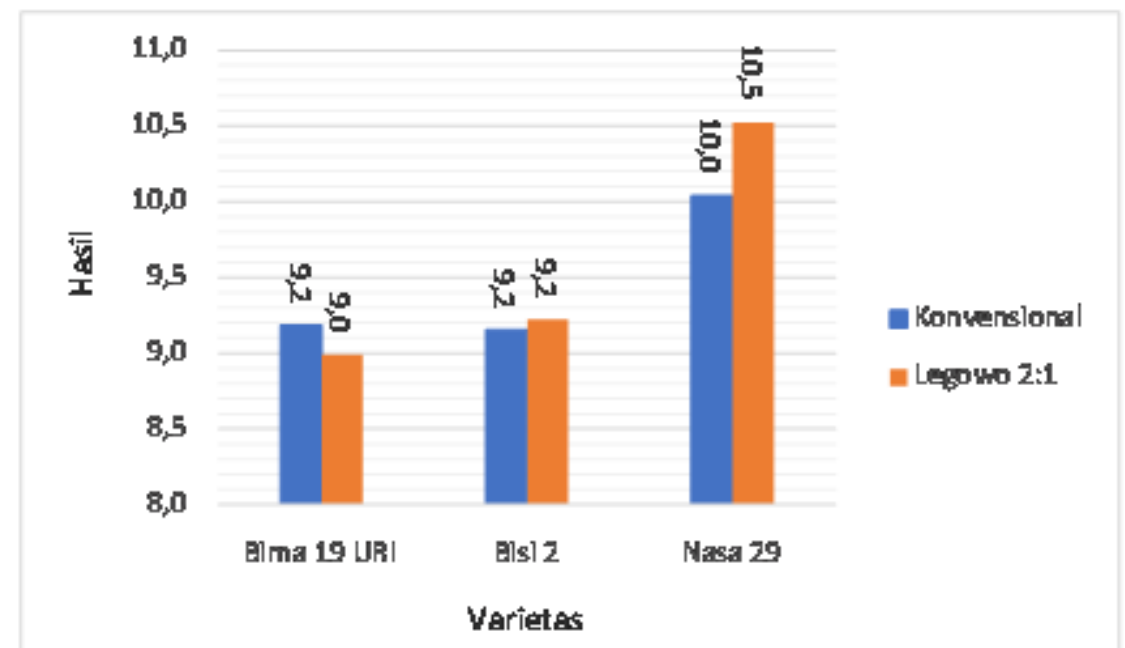

Gambar 3. Rata-rata hasil beberapa varietas jagung yang ditanam pada sistem tanam yang berbeda

\section{b. Pembahasan}

Respon Pertumbuhan dan Produksi
antara Beberapa Varietas

Varietas Bisi 2 merupakan varietas jagung yang mempunyai respon pertumbuhan yang baik karena berpengaruh nyata terhadap peubah yang diamati diantaranya memiliki tinggi tanaman yang tertinggi dan memiliki daun yang terpanjang sedangkan respon produksi yang baik adalah varietas Nasa 29 yang berpengaruh nyata terhadap peubah panjang tongkol terpanjang dibandingkan varietas lainnya.

Perbedaan morfologi baik tinggi tanaman maupun panjang daun yang terjadi antara varietas Bima 19 URI, Bisi 2 dan Nasa 29 yang diteliti salah satu penyebab keragaman penampilan tanaman adalah susunan genetiknya (Sitompul dan Guritno, 1995). Genetik yang akan diekspresikan pada suatu fase pertumbuhan yang berbeda dapat diekspresikan pada berbagai sifat tanaman yang mencakup bentuk dan fungsi tanaman yang menghasilkan keragaman pertumbuhan tanaman. Ihsan et al. (2005), menambahkan bahwa pengujian tanaman hibrida pada peubah-peubah morfologi menunjukkan variasi yang berbeda pada peubah-peubah tersebut.

Varietas Nasa 29 merupakan varietas jagung yang memiliki panjang tongkol terpanjang dibandingkan varietas Bima URI 29 dan Bisi 2. Berdasarkan hasil penelitian yang dilakukan varietas Nasa 29 diperoleh panjang tongkol 18.6 $\mathrm{cm}$ dan berbeda nyata terhadap varietas Bima 19 URI dengan rata-rata panjang tongkol $16.6 \mathrm{~cm}$ dan varietas Bisi 2 dengan rata-rata panjang tongkol $17.4 \mathrm{~cm}$. Begitu pula dengan produksi tertinggi 
adalah varietas NASA 29 diperoleh hasil 10.5 ton per hektar lebih tinggi dibandingkan varietas Bima 19 URI diperoleh hasil 9 ton per hektar dan Bisi 2 diperoleh hasil 9.2 ton per hektar.

\section{Respon Pertumbuhan dan Produksi Tanaman Jagung pada Sistem Tanam Berbeda}

Berdasarkan hasil penelitian terhadap pertumbuhan dan produksi tanaman jagung pada sistem tanam berbeda menunjukkan sistem tanam konvensional yang baik berpengaruh terhadap peubah yang diamati yaitu diameter tongkol.

Sistem tanam konvesional memberikan hasil diameter tongkol dengan rata-rata $46.51 \mathrm{~mm}$ lebih besar diameternya dibandingkan sistem tanam legowo 2:1 dengan rata-rata diameter tongkol $44.97 \mathrm{~mm}$. Sistem tanam legowo 2:1 memiliki salah satu jarak antar baris yang lebih rapat dibandingkan dengan sistem tanam konvesional yang jarak antar baris yang sama sehingga semua bagian tanaman mendapatkan pencahayaan, unsur hara, air yang hampir semua sama jika dibandingkan dengan sistem tanam legowo 2:1 ada salah satu sisi bagian tanaman jagung yang rapat sehingga permukaan daun saling menutup, sehingga menghambat proses fotosintesis. Proses fotosintesis yang terhambat akan berdampak pada jumlah fotosintat yang dihasilkan. Hal tersebut dikaitkan dengan persaingan untuk mendapatkan hasil asimilasi, karena fotosintesis berkurang dalam tegakan yang rapat (Gardner et al., 1991), sehingga diameter tongkol lebih maksimal dengan sistem tanam konvensional.

Hasil per hektar sebaliknya sistem tanam legowo 2:1 memberikan produksi lebih tinggi dibandingkan sistem tanam konvesional. Sistem tanam legowo 2:1 cenderung menunjukkan hasil tertinggi pipilan kering pada semua varietas yang diuji. Hasil per hektar diperoleh hasil tertinggi 10.5 ton per hektar dibandingkan sistem tanam konvesional pada varietas Nasa 29 dan Bisi 2.

\section{Interaksi antara Beberapa Varietas dan Sistem Tanam Berbeda}

Berdasarkan hasil penelitian terhadap peubah yang diamati terhadap pertumbuhan dan produksi tanaman jagung menunjukkan terdapat interaksi antara beberapa varietas dan sistem tanam berbeda, peubah yang berpengaruh tinggi tanaman dan diameter tongkol. 
Interaksi varietas dan sistem tanam disebabkan oleh adanya perbedaan pada respon pertumbuhan terhadap kecepatan pembelahan, perbanyakan, dan perubah yang diamati tinggi tanaman pembesaran sel. Handayani (2003) tertinggi terjadi pada varietas Bisi 2 pada menyatakan bahwa diameter tongkol sistem tanam konvensional yang memiliki dipengaruhi oleh varietas. tinggi tanaman tertinggi dengan rata - rata $240.722 \mathrm{~cm}$ ini disebabkan karena dkk.(1991) yang menyatakan bahwa susunan genetik setiap verietas berbedabeda. Genetik yang akan diekspresikan pada suatu fase pertumbuhan yang berbeda dapat diekspresikan pada berbagai sifat tanaman yang mencakup bentuk dan fungsi tanaman yang menghasilkan keragaman pertumbuhan tanaman. Ihsan et al. (2005), menambahkan bahwa pengujian tanaman hibrida pada peubah-peubah morfologi menunjukkan variasi yang berbeda pada peubah-peubah tersebut.

Respon produksi yang terjadi pada peubah yang diamati yaitu diameter tongkol yang berpengaruh nyata terjadi interaksi varietas Bima 19 URI pada sistem tanam legowo diperoleh rata-rata $48.728 \mathrm{~mm}$ terbesar dibandingkan varietas Bisi 2 dan Nasa 29. Varietas unggul menghasilkan diameter tongkol yang lebih besar dibanding varietas lokal. Penampilan diameter tongkol yang berbeda antara varietas yang diuji diduga

pengaruh varietas terhadap variabel yang diamati disebabkan oleh adanya perbedaan faktor genetik yang dimiliki masing-masing varietas jagung dan kemampuan adaptasinya terhadap lingkungan, sedangkan untuk hasil per hektar Nasa 29 pada sistem tanam legowo menghasilkan produksi tertinggi diperoleh 10.5 ton per hektar.

\section{KESIMPULAN DAN SARAN}

\section{Kesimpulan}

1. Jagung varietas Bisi 2 mempunyai pertumbuhan yang baik, yang diperlihatkan oleh tinggi tanaman yang tertinggi dan mempunyai daun yang terpanjang. Varietas Nasa 29 menghasilkan panjang tongkol terpanjang dibandingkan varietas lainnya.

2. Sistem tanam konvesional diperoleh diameter tongkol yang lebih besar yaitu $46.51 \mathrm{~mm}$ dibandingkan sistem 
tanam legowo 2:1 dengan rata-rata

diameter tongkol $44.97 \mathrm{~mm}$.

3. Interkasi antara varietas Bisi 2 dengan sistem tanam konvensional diperoleh tongkol dengan diameter tongkol terbesar.

\section{DAFTAR PUSTAKA}

BPS (Badan Pusat Statistik). 2016. Produksi, Luas Panen dan Produktivitas Jagung di Provinsi Sulawesi Selatan. bps.go.id. Badan Pusat Statistik. Makassar.Sulawesi Selatan (Diakses 17 Desember 2016).

Gardner, C, A, C, dkk. 1990. Response Hybrid Jo Nitrogen Fertilizer. J. Prod. Agric. 3 (1): hal 39 \& 43

Gardner FP, Pearce RB, and Mitchell RL. 1991. Physiology of Crop Plants.Diterjemahkan oleh H.Susilo. Jakarta. Universitas Indonesia Press.

Handayani, K.D. 2003. Pertumbuhan dan Produksi Beberapa Varietas Jagung (Zea mays L). pada Populasi yang
Berbeda dalam Sistem Tumpang Sari dengan Ubi Kayu (Manihot esculenta Crants.). Skripsi: Departemen Budidaya Pertanian, Fakultas Pertanian, Institut Pertanian Bogor. Bogor.

Ihsan, H., I.H. Khalil, H. Rahman and M.Iqbal. 2005. Genotypic Variability formorphologicaltraits among exotic maize hybrids. Sarhad J. Agric. 21 (4): 599-602.

Sitompul, S.M. dan B. Guritno. 1995. Analisis Pertumbuhan Tanaman. Yogyakarta. Gadjah Mada University.

Suryana, A., Darmadjati, D.S., Subandi, Kariyasa, K., Zubachtirodin dan Saenong, S. 2005. Prospek dan Arah Pengembangan Agribisnis Jagung.

Suprapto dan Nyoman, A.J. 2000. Berbagai Masukan Teknologi untuk Meningkatkan Produktivitas Lahan Marginal. Laporan Akhir Penelitian SUT Diversivikasi Lahan Marginal di Kecamatan Gerokgak. Buleleng Dalam No.Agdex 100/16. No. Seri Il/Tanaman/z\}\}DD Oktober 2000. Instalasi Penelitian dan Pengkajian Telmologi Pertanian Denpasar: Bali. 